\title{
Molecular, morphological and acoustic identification of Eumops maurus and $E$. hansae (Chiroptera: Molossidae) with new reports from Central Amazonia
}

ADRIÀ LÓPEZ-BAUCELLS ${ }^{\mathrm{a}, \mathrm{b}, \mathrm{c}, \mathrm{d} *}$, RICARDO ROCHA ${ }^{\mathrm{a}, \mathrm{c}, \mathrm{d}}$, VALÉRIA DA CUNHA TAVARES ${ }^{\mathrm{e}, \mathrm{f}}$, LIGIANE MARTINS MORAS ${ }^{\mathrm{e}}$, SARA EMA SILVA ${ }^{\mathrm{a}}$, PAULO ESTEFANO DINELI BOBROWIEC ${ }^{\mathrm{c}}$, CHRISTOPH F.J. MEYER ${ }^{\mathrm{a}, \mathrm{c}, \mathrm{g}}$

${ }^{a}$ Centre for Ecology, Evolution and Environmental Changes (cE3c). Faculty of Sciences, University of Lisbon, Building C2, Campo Grande, 1749-016 Lisboa (Portugal)

${ }^{\mathrm{b}}$ Granollers Museum of Natural Science, Bat Research Group. c/Palaudàries, 102 - Jardins Antoni Jonch Cuspinera, 08402 Granollers, Catalonia (Spain)

${ }^{\mathrm{c}}$ Biological Dynamics of Forest Fragments Project, Instituto Nacional de Pesquisas da Amazônia (INPA). Av. André Araujo, 2936, 69067-375 Manaus AM (Brazil)

${ }^{\mathrm{d}}$ Metapopulation Research Group, University of Helsinki. Department of Biosciences, PO Box 65, Viikinkaari 1, FI-00014 Helsinki (Finland)

${ }^{\text {e }}$ Departamento de Zoologia, Universidade Federal de Minas Gerais (UFMG), Av. Antônio Carlos, 6627, MG-31270-901, Belo Horizonte, Minas Gerais MG (Brazil)

${ }^{\mathrm{f}}$ Departamento de Biologia, Universidade Estadual de Minas Gerais (UEMG), Av. São Paulo, 3996, MG-32400-000 Ibirité MG (Brazil)

g School of Environment and Life Sciences, University of Salford, M5 4WT Salford (United Kingdom)

* Corresponding author: adria.baucells@gmail.com // +4407843702369

\section{Orcid identifiers:}

Adrià López-Baucells: orcid.org/0000-0001-8446-0108

Ricardo Rocha: orcid.org/0000-0003-2757-7347

Valéria da Cunha Tavares: orcid.org/0000-0003-0966-0139

Sara Ema Silva: orcid.org/0000-0001-8766-8131

Paulo Estefano Dineli Bobrowiec: orcid.org/0000-0002-8945-6105

Christoph Meyer: orcid.org/0000-0001-9958-8913 
Short running title: Identification of poorly known molossids from Central Amazonia.

Words: 5182 


\begin{abstract}
Eumops maurus and E. hansae are rarely captured Neotropical molossid bats for which information on taxonomy, natural history, and spatial distribution are scarce. This translates into a poor understanding of their ecology and limits the delimitation of useful characters for their identification. Here, we describe records of these two molossids from the Central Brazilian Amazon, providing data on their external and craniodental morphology, DNA barcode (COI) sequences complemented by acoustic data for the species. Morphological characters, DNA sequence data and phylogenetic relationships within the genus Eumops were consistent with those previously described for both species. Echolocation call characteristics did not differ significantly so as to be useful for separating E. maurus and E. hansae from other congeners. Our records are, respectively the first and the second for Central Amazonia as one individual previously attributed to E. amazonicus from Manaus may be considered a junior synonym for $E$. hansae. These new records increase the extent of the species' known ranges, partially filling in previous existing gaps in their distribution in central South America. Our data further suggest that these molossid bats forage in a wider range of habitats than previously thought.
\end{abstract}

Keywords: Amazonian rainforest, Barcoding, Bioacoustics, Brazil, Echolocation, Systematics, Taxonomy. 


\section{Introduction}

The Molossidae are a diverse family of aerial insectivorous bats, with more than 100 extant species whose center of richness is in tropical and subtropical regions (Gregorin et al. 2016; Simmons 2005). Due to their high-flying habits of foraging above forest canopies and over open landscapes, molossids are usually hard to capture using ground level mist-nets, as a consequence of which knowledge of their ecology and distribution is still limited (Barataud et al. 2013; Gregorin, et al. 2016; Jung et al. 2014). Moreover, the relatively few records of molossids often come from colonies found within urban areas, leading to the biased perception that these bats may particularly be associated with anthropic environments (López-Baucells et al. 2017a; Sodré et al. 2008). Overall, data on molossid species from South America are scarce and despite the fact that multidisciplinary research on these bats is globally increasing (Gager et al. 2016) their natural history remains largely unknown, particularly for some of the more elusive species.

Bonneted bats of the genus Eumops Miller, 1906 are widely distributed throughout the New World, ranging from the southeastern United States to Patagonia, including some Antillean islands (Gardner 2008). Eumops is one of the most diverse molossid genera with 17 species currently recognized (Gregorin, et al. 2016). However, knowledge about the distributions of Eumops species is limited (Medina et al. 2012). Moreover, the taxonomy of the genus is in flux, as recently several previously unrecognized species have been described and the phylogeny of Eumops has been revised (Bartlett et al. 2013; Gregorin 2009; Gregorin, et al. 2016; Medina et al. 2014).

Both Sanborn's Bonneted Bat, Eumops hansae Sanborn, 1932, and the Guianan Bonneted Bat E. maurus (Thomas, 1901) are widely distributed throughout the Neotropics, but rarely captured. Their occurrence has been documented only through a handful of records across their 
distributional ranges. While E. hansae has been recorded in 12 countries across Central and South America, E. maurus is only known from eight localities from Guiana, Brazil, Venezuela, Peru and Ecuador (Fig. 1). Not only are the ranges of these two species still poorly documented, but also basic natural history, ecological and genetic data are scarce and their echolocation calls remain undescribed (Best et al. 2001a, b). Here, we present data on the morphology, echolocation, and mitochondrial DNA of E. hansae and E. maurus from the Central Brazilian Amazon. We discuss the potential of each kind of information to aid in the reliable identification of the two species. 


\section{Material and Methods}

Study area

Field work was carried out at the Biological Dynamics of Forest Fragmentation Project (BDFFP), located ca. $80 \mathrm{~km}$ north of Manaus in the Central Amazon, Brazil $\left(2^{\circ} 25^{\prime} \mathrm{S}, 59^{\circ} 50^{\prime} \mathrm{W}\right.$; elevation 30-125 m a.s.1.) (Lovejoy and Bierregaard 1990). The predominant vegetation in this region is lowland primary terra firme forest (Bruna and Kress 2002), with minor areas of secondary forest (8,325ha). Mean annual temperature is $26^{\circ} \mathrm{C}$ (de Oliveira and Mori 1999) and annual rainfall ranges from $1,900-3,500 \mathrm{~mm}$, with a rainy season from October to May. The primary forest canopy is 30-37 $\mathrm{m}$ tall, with emergent trees up to $55 \mathrm{~m}$ (Laurance et al. 2017).

[Figure 1 near here]

Bat sampling

Extensive standardized mist-netting was carried out across the BDFFP landscape between 2011 and 2014 as part of a comprehensive project on the effects of forest fragmentation on phyllostomid bats (Farneda et al. 2015; Rocha et al. 2017). Additionally, during the same period mist nets (12x2.5 m, $16 \mathrm{~mm}$ mesh, ECOTONE, Sopot, Poland) were also set opportunistically across streams and small lakes, both during the rainy and the dry season. Nets were left open for six hours after sunset and checked every 20-30 minutes. This opportunistic sampling resulted in captures of three adult males of E. maurus and three adult females of E. hansae over natural lakes, one in the $\mathrm{Km} 41$ reserve $\left(2^{\circ} 26^{\prime} 51.69^{\prime \prime} \mathrm{S}, 59^{\circ} 45^{\prime} 2.05^{\prime \prime} \mathrm{W}\right)$ and one in Colosso reserve (2²4'39.34"S, 59 52'8.55"W), between April and June 2014. All bats were captured in different nights. Lakes measured approximately 100x112 and 80x55 m respectively, and were up to $2 \mathrm{~m}$ deep. Both lakes underwent seasonal water level fluctuations, but carried water throughout the 
year. However, they greatly differed regarding human use. The lake in Colosso was used as a water reservoir for cattle and horses, whereas the one in $\mathrm{Km} 41$ is located far away from human settlements and surrounded by primary forest.

One individual per species was collected as voucher specimen. From all individuals, including the ones that were released, standard external measurements were taken in the field (see below). We also took wing tissue samples using commercial wing biopsy punches $(2 \mathrm{~mm}$, Stiefel Laboratories, Inc., Germany). Voucher specimens were deposited at the Mammal Collections of the Instituto Nacional de Pesquisas da Amazônia (INPA 6731 Eumops maurus; INPA 6732 Eumops hansae) in accordance with Brazilian conservation and animal welfare laws. Research was carried out under scientific license from the Instituto Chico Mendes de Conservação da Biodiversidade-ICMBio (permit number 26877-2).

\section{Morphology}

External and craniodental characters measured are based on Eger (1977) and Freeman (1981), and were recorded in millimeters (mm) using digital calipers accurate to $0.1 \mathrm{~mm}$ (Fig. 2). Body mass was recorded in grams (g) with a Pesola spring scale (accuracy of $0.5 \mathrm{~g}$ ). Measurements are defined as follows: total length (TL); tail (TAIL); thumb length (ThL); nail (Na); calcar length (Cal); antitragus width (AntW); antitragus height (AntH); hind foot length (HF); ear length (E); forearm length (FA); tibia length (TiL); fourth metacarpal length (MET-IV); first phalanx of the fourth digit (PHA1-IV); greatest length of the skull (GLS); condyloincisive length (CIL); zygomatic breadth (ZB); postorbital breadth (PB); braincase breadth (BB); maxillary toothrow length (MTRL); breadth across molars (BAM); breadth across canines (BAC); mandibular toothrow length (MANDL) and mandibular length (MANDLT). 
[Figure 2 near here]

\section{Echolocation recordings}

Echolocation call recordings were obtained from captured individuals (two individuals per species were recorded) using a Pettersson D1000X detector (Pettersson Elektronik AB, Uppsala, Sweden) after each individual's release in forest clearings. To minimize bias in acoustic parameters, only those sequences recorded at least 5 seconds after the release (when the bats were normally flying at higher altitudes) were considered for analysis. Individual Eumops hansae were easily released from the hand as their small size allows them to take off even in quite cluttered environments from relatively low heights (they are more maneuverable than other molossid species), despite their narrow wings. With Eumops maurus the release process was slightly more complicated and we tried to facilitate their take-off by placing the bats high up on the trunks of dead trees or on poles. The detector was placed $15 \mathrm{~m}$ away from the animals. Recordings were made at a sampling frequency of $250 \mathrm{kHz}$, with $16 \mathrm{bits} / \mathrm{sample}$. For sound analysis, we used a customized 512 point fast Fourier transform (FFT) with a Hanning window for both spectrograms and power spectrum. To characterize the echolocation calls, the following parameters were measured from 24 pulses for E. hansae and 49 pulses for E. maurus, using Kaleidoscope v.3.1.4b (Wildlife Acoustics, USA): peak frequency or frequency with maximum energy (FME), start frequency (St-freq) and end frequency (End-freq) (Jung, et al. 2014; LópezBaucells et al. 2016a). Other common measurements such as bandwidth and pulse duration were not considered as they are particularly prone to be biased after hand release. To minimize measurement error and bias, we only measured those pulses from the recorded echolocation call sequences whose intensity was around $20 \mathrm{~dB}$ higher than the background noise. 


\section{DNA barcoding and phylogenetic analyses}

DNA of the two Eumops species was extracted from muscle tissue of the collected individuals. For preserved tissue samples, PCR amplifications of COI were carried out in $15 \mu \mathrm{L}$ reactions containing $60 \mathrm{ng}$ of DNA, $1.5 \mathrm{U}$ of Platinum Taq (Invitrogen ${ }^{\circledR}$, Carlsbad, CA, USA), $1 \mathrm{x}$ Platinum Taq PCR buffer, $1.5 \mathrm{mM} \mathrm{MgCl} 2,200 \mu \mathrm{M}$ dNTPs set (Invitrogen ${ }^{\circledR}$ ) and $0.3 \mu \mathrm{M}$ of each primer. The primers used for amplifications were modified from Folmer et al. (1994), available from the BOLD project (Ratnasingham \& Hebert, 2007). We used the following cycling scheme for PCRs: 2 min at $94^{\circ} \mathrm{C}$ followed by 35 cycles of $30 \mathrm{~s}$ at $94^{\circ} \mathrm{C}, 40 \mathrm{~s}$ at $50^{\circ} \mathrm{C}$ for primer annealing and $1 \mathrm{~min}$ at $72^{\circ} \mathrm{C}$ for extension, and a final $10 \mathrm{~min}$ extension at $72^{\circ} \mathrm{C}$ after the last cycle. Sequencing of both strands was carried out on an ABI 3130 (Applied Biosystems ${ }^{\circledR}$ ) automated sequencer using Big Dye Terminator Cycle Sequencing methodology (Applied Biosystems $\left.{ }^{\circledR}\right)$. The sequences produced in this study were deposited in the BOLD database (http://www.boldsystems.org) under the process ID BRMAM620-15.

We retrieved sequence data available for six species of Eumops and also for Tadarida brasiliensis (outgroup) from BOLD and GenBank to perform phylogenetic analyses for the genus, and to infer the position of our specimens in the phylogeny. GenBank accession numbers are given in Table S1. We used MEGA 6 (Tamura et al. 2013) to align and edit the sequences, and to calculate genetic distances based on a Kimura 2-parameter (K2P) model (Kimura 1980). Partition Finder 1.0.1 (Lanfear et al. 2012) was used to select the best partitions and models of sequence evolution for phylogenetic inference, whereby fit was assessed by Akaike's information criterion (AIC) (Akaike 1974). Phylogenetic relationships were inferred using Maximum Likelihood (ML) and Bayesian analysis methods as implemented respectively in RAxML v8.2.0 (Stamatakis 2014) and MrBayes v3.2.4 (Ronquist et al. 2012). For the Bayesian 
analysis, the three codon positions were analyzed separately under the following models: SYM+I for the first codon position, HKY for the second codon position and GTR $+\mathrm{G}$ for the third codon position. A run with 4 chains was conducted for 20,000,000 generations (sampled every 200 generations). The first $10 \%$ of trees were discarded as burn-in, and the remainder was used to estimate tree parameters and topology. Trees were visualized in FigTree v1.4.2 (http://tree.bio.ed.ac.uk/software/figtree/). Maximum Likelihood analyses were conducted using the GTRCAT substitution model with 1,000 bootstrap replicates. 


\section{Results \\ Morphology}

We identified Eumops hansae based on a combination of characters, including its (i) small size (FA $=38.7 \mathrm{~mm}$, Table 1), (ii) ears connected by a membranous stripe on the forehead, (iii) square-shaped tragus, and (iv) blackish brown dorsal pelage contrasting with the paler venter with three-colored banded fur. Our female specimen had a long skull with large and well-defined basisphenoid pits (Fig. 2D-F), and the third commissure of M3 nearly as well developed as the second (Fig. 2E). Individuals of E. maurus (all males) were readily identified based on external measurements (Table 2), the species' distinctive band of pure white hairs in the proximal ventral plagiopatagium (measuring approximately $5 \times 20 \mathrm{~mm}$ ), and the narrow band along the lateral body. The skull of our specimen had paired oval, and relatively shallow pits in its basisphenoid bone, and small anterior upper premolars (Fig. 2).

[Table $1 \& 2$ near here]

Echolocation calls

Echolocation calls of both E. maurus and E. hansae consisted of a quasi-constant frequency (QCF) component, and were almost constant at very low frequencies (Table 3, Fig. 3). As usual for molossids, the fundamental was the harmonic with the maximum energy in both cases. For $E$. maurus, peak frequency averaged $25.3 \mathrm{kHz}$, ranging between 19-30 kHz. Eumops hansae emitted low-frequency QCF pulses at a peak frequency of $21.9 \mathrm{kHz}$ (range 18-24 kHz). For both species, the shape of the pulses was clearly concave and downward modulated, being the first part of the pulse highly modulated, and the terminal part almost constant. Based on our recordings there was no evidence of pulse alternation in either species. 
[Table 3 near here] [Figure 3 near here]

DNA barcoding and phylogenetic analyses

Average pairwise COI distances between Eumops species ranged from 3.2\% (E. auripendulus versus E. maurus) to $17.4 \%$ (E. hansae versus E. perotis) (Table 4 \& 5), and intraspecific genetic distances ranged from $0 \%$ (E. maurus and E. floridanus) to $0.9 \%$ (E. hansae). Sequence similarity between the individuals of $E$. hansae from Guiana and our specimen from Brazil was high (99.3 - 99.8\%). In contrast, similarity between our Brazilian specimen and the sequence from a single individual from Belize was considerably lower (96.3\%). For E. maurus, the single published barcoding sequence comes from Guiana (Clare et al. 2011), and fully (100\%) matched the sequence obtained for our Brazilian specimen.

Our specimen of $E$. hansae formed a clade with a specimen from Guiana, nested within a clade composed of representatives from Belize and several other individuals from Guiana, sister to all other Eumops species included in this analysis. The samples of E. maurus from Ecuador and Brazil formed a well-supported sister clade to E. auripendulus (Fig. 4).

[Table $4 \& 5$ near here] [Figure 4 near here] 


\section{Discussion}

We used multiple methodological approaches in combination (external and craniodental morphology, DNA barcode and acoustic data) to confirm new occurrence records for 2 poorly known molossid species. Despite the clear advantages and improvements that multidisciplinary studies provide to scientists, they are still fairly rare within the literature, especially on tropical bat species (but see Gager, et al. 2016). Such integrative studies should be widely encouraged, as they can advance the further description and understanding of the diversity of bat species across the continent more efficiently than single-method studies.

\section{Species distribution}

Taxonomic uncertainties of $E$. hansae have led to knowledge on its natural history and current distribution lagging considerably behind that for other Neotropical molossids (Bartlett, et al. 2013). Although being one of the least known Eumops species, E. hansae had previously been captured in a wide range of habitats. These include forests off coastal areas (Álvarez-Castañeda and Álvarez 1991; Koopman 1982), tropical rainforests (Eisenberg 1989; Lee and Bradley 1992; Paglia et al. 2012; Simmons and Voss 1998), savannas (Ibáñez and Ochoa 1989), premontane humid forests (Ochoa et al. 1988), dry forests (Pineda et al. 2008), and tropical lowland forest in hilly terrains (Graham and Barkley 1984). However, despite the broad range of habitats where it has been found, captures were almost always over ponds, large clearings, rivers and large lagoons. The presence of this species in such a diverse range of environments suggests that $E$. hansae is not restricted to a particular habitat, and could in fact be widespread (Fig. 1). Eumops maurus inhabits a diverse array of habitats, including savannas, although it is often associated with swamps dominated by the palm Mauritia flexuosa, gallery forests, swampy evergreen forest 
and urban spaces (Best, et al. 2001b; Sodré, et al. 2008). Overall, specimens from only seven localities are known for this poorly known bat (Fig. 1) comprising a total of six females and a single male from Guiana, the holotype. Our records from Manaus (3 males) fill a gap in the center of the previously known distribution (Fig. 1) representing a westward range expansion of $1900 \mathrm{~km}$ from Corumbá (Brazil) and $620 \mathrm{~km}$ southward from the Kanaku mountains (French Guiana: Sodré, et al. (2008)). Of the three individuals, one voucher was collected, which represents the second male specimen available in collections.

Morphology

Morphological variation within molossids makes reliable species identification sometimes difficult and may lead to inconsistent results among studies (Gregorin 2009), particularly if based mostly on continuous characters. That is, for instance, the case for the use of forearm length to separate E. maurus from other Eumops species. In these cases, sometimes consistent discrete characters, such as the presence of the large lateral stripe of white ventral fur alongside its body, and the oval shaped, relatively shallow pit in its basisphenoid bone (Best, et al. 2001b; Gregorin 2009), make E. maurus easy to identify. As reported previously for specimens from Surinam, there was a small anterior upper premolar present in our voucher, which Eger (1977) reported to be absent in the holotype, and therefore this character may be considered a variable condition for the species. Our specimen of E. maurus has a somewhat smaller forearm compared to the range of forearm lengths of specimens from other localities, including the holotype (male) collected in Guiana (Table 2). Cranial measurements of our specimen did not differ much from those of the holotype. Unfortunately, no additional E. maurus male skull measurements are available for comparison. Based on the sparse cranial measurements available for male and female E. maurus we tentatively posit that males have somewhat longer skulls than females, but are otherwise 
similar in size. All measurements from E. hansae fell within the expected range for the species, and the few measurements available for males were larger than those for females (Table 1).

\section{Echolocation calls}

In contrast to other families, most molossid species are known to forage in open spaces adapting their echolocation to long-range prey detection. Like their congeners, quasi-constant frequency pulses characterize the echolocation calls of E. maurus and E. hansae and reflect their adaptation to flying in open spaces (Aldridge and Rautenbach 1987; Russo and Jones 2002). There is a considerable overlap in peak frequency between E. maurus and other Eumops species, including E. hansae, E. auripendulus, E. glaucinus, and E. dabbenei (Table 3, Fig. 3) thus rendering this parameter useless for species identification. Some Neotropical molossids such as Molossus molossus, M. rufus and Promops centralis can be easily identified acoustically based on the alternation of pulses, call shape (concave vs convex or upward- versus downward-modulated for instance), and peak frequencies (Barataud, et al. 2013; Jung, et al. 2014; López-Baucells, et al. 2016a). Unfortunately, based on our recordings, no parameter was found to be diagnostic so as to allow reliable discrimination between either of the two Eumops species. Until more acoustic data become available, allowing for a comprehensive genus-wide analysis, we recommend grouping all species from the genus Eumops into a single phonic group. The fact that we could not find any pulse alternation could result from the stress caused by the handling and the proximity of cluttered forest where they were released. More calls recorded under natural conditions would be essential to complement the description of the echolocation call characteristics of the species. The fact that other poorly studied species of Eumops have similar calls stresses the need for further studies to evaluate additional criteria for their acoustic discrimination. 


\section{DNA barcoding and phylogenetic analyses}

Cytochrome c Oxidase subunit I (COI) has been proposed as a global scale barcode for animal species identification (Kress et al. 2015; Ratnasingham and Hebert 2007) and has already been successfully used to aid in the identification and discovery of Neotropical bats (Clare et al. 2013; Lim and Arcila Hernandez 2015). Our sequences from E. hansae and E. maurus were properly classified at species level using the DNA barcode database. This corroborates, as suggested by Clare, et al. (2011), that DNA barcoding is a powerful auxiliary tool to identify specimens. While COI sequences available in GenBank are still scarce for E. maurus, for E. hansae several sequences can be found. Nevertheless, for both of these Eumops species and congeners there are large sampling gaps throughout their distribution range. The position of E. hansae within the Eumops tree has shifted historically to either basal to all species of Eumops, or nested with small Eumops (Bartlett, et al. 2013; Gregorin, et al. 2016). Our phylogenetic analyses recovered E. hansae as sister to all other Eumops, as did the concatenated data of Bartlett, et al. (2013) and Gregorin, et al. (2016). Alternatively, E. hansae has been previously hypothesized to be sister to all small-sized Eumops (bonariensis, patagonicus, nanus) based on molecular (Medina, et al. 2014) and morphological evidence (including delticus) (Gregorin 2009, Medina, et al. 2014). On the other hand, the position of E. maurus within Eumops seems more stable as this taxon is frequently recovered as the sister of auripendulus based both on molecular (Bartlett, et al. 2013; Gregorin, et al. 2016; Medina, et al. 2014) and morphological data (Gregorin 2009).

DNA barcoding is still not always employed in studies that report new species occurrences or distribution range expansions in many taxa (Bezerra et al. 2005; Khedkar et al. 2016; LópezBaucells et al. 2013, 2014; Moras et al. 2015; Tavares et al. 2014; but see Khedkar, et al. 2016; López-Baucells et al. 2016b, 2017b; Nagy, et al. 2012; Seyhan and Turan 2016). Its increasingly 
common use as a supporting tool for inventories will certainly accelerate the study and description of Neotropical bat diversity. 


\section{Acknowledgments}

We would like to thank Oriol Massana, Diogo Ferreira, Marta Acácio, Fabio Farneda, Gilberto Fernández and Madalena Boto for fieldwork assistance and José Luis Camargo, Rosely Hipólito, and Ary Jorge Ferreira for logistic support. We thank INPA for providing the research permits to capture and collect bat specimens within the study area. This work was financially supported by the Portuguese Foundation for Science and Technology under project grant PTDC/BIABIC/111184/2009 (CFJM), and scholarships SFRH/BD/80488/2011 (RR) and $\mathrm{PD} / \mathrm{BD} / 52597 / 2014$ (ALB). VCT is supported by a PNPD/CAPES fellowship program. This is publication XXX in the Technical Series of the BDFPP. This research has been carried out under ICMBio permit (26877-2). Finally, we thank two anonymous reviewers for their constructive comments on an earlier version of the manuscript. 


\section{Literature cited}

Akaike H. 1974. A new look at the statistical model identification. IEEE transactions on automatic control. 19(6):716-723. doi https://doi.org/10.1109/TAC.1974.1100705

Aldridge H, Rautenbach IL. 1987. Morphology, echolocation and resource partitioning in insectivorous bats. Journal of Animal Ecology. 56(3):763-778. doi http://dx.doi.org/10.2307/4947

Álvarez-Castañeda ST, Álvarez T. 1991. Los murciélagos de Chiapas. Mexico: Instituto Politecnico Nacional, Escuela Nacional de Ciencias Biológicas.

Barataud M, Giosa S, Leblanc F, Rufray V, Disca T, Tillon L, Delaval M, Haquart A, Dewynter M. 2013. Identification et écologie acoustique des chiroptères de Guyane française. Le Rhinolophe. 19(1):103-145

Bartlett SN, McDonough MM, Ammerman LK. 2013. Molecular systematics of bonneted bats (Molossidae: Eumops) based on mitochondrial and nuclear DNA sequences. Journal of Mammalogy. 94(4):867-880. doi http://dx.doi.org/10.1644/12-mamm-a-134.1

Best TL, Hunt JL, McWilliams LA, Smith KG. 2001a. Eumops hansae. Mammalian Species. $687: 1-3$

Best TL, Hunt JL, McWilliams LA, Smith KG. 2001b. Eumops maurus. Mammalian Species. $667: 1-3$

Bezerra AMR, Escarlate-Tavares F, Marinho J. 2005. First record of Thyroptera discifera (Chiroptera : Thyropteridae) in the Cerrado of Central Brazil. Acta Chiropterologica. 7(1):165-170. doi http://dx.doi.org/10.3161/1733-5329(2005)7[165:FROTDC]2.0.CO;2

Bruna EM, Kress WJ. 2002. Habitat fragmentation and the demographic structure of an amazonian understory herb (Heliconia acuminata). Conservation Biology. 16(5):1256-1266. doi http://dx.doi.org/10.1046/j.1523-1739.2002.99494.x

Clare E, Adams A, Maya-Simoes A, Eger J, Hebert P, Fenton MB. 2013. Diversification and reproductive isolation: cryptic species in the only New World high-duty cycle bat, Pteronotus parnellii. BMC Evolutionary Biology. 13(26):1-18. doi http://dx.doi.org/10.1186/1471-2148-13-26

Clare EL, Lim BK, Fenton MB, Hebert PDN. 2011. Neotropical bats: estimating species diversity with DNA barcodes. PLoS ONE. 6(7):e22648. doi http://dx.doi.org/10.1371/journal.pone.0022648

de Oliveira AA, Mori SA. 1999. A central Amazonian terra firme forest. I. High tree species richness on poor soils. Biodiversity and Conservation. 8(9):1219-1244. doi http://dx.doi.org/10.1023/A:1008908615271

Eger JL. 1977. Systematics of the genus Eumops (Chiroptera, Molossidae). Toronto: Royal Ontario Museum.

Eisenberg JF. 1989. Mammals of the Neotropics 1. The northern neotropics: Panama, Colombia, Venezuela, Guyana, Suriname, French Guiana. Chicago: University of Chicago Press.

Farneda FZ, Rocha R, López-Baucells A, Groenenberg M, Silva I, Palmeirim JM, Bobrowiec PED, Meyer CFJ. 2015. Trait-related responses to habitat fragmentation in Amazonian bats. Journal of Applied Ecology 52(5):1381-1391. doi 10.1111/1365-2664.12490 
Freeman PW. 1981. A multivariate study of the family Molossidae (Mammalia, Chiroptera): morphology, ecology, evolution. Lincoln, Nebraska: Field Museum of Natural History

Gager Y, Tarland E, Lieckfeldt D, Menage M, Botero-Castro F, Rossiter SJ, Kraus RH, Ludwig A, Dechmann DK. 2016. The Value of Molecular vs. Morphometric and Acoustic Information for Species Identification Using Sympatric Molossid Bats. PLoS ONE. 11(3):e0150780. doi http://dx.doi.org/10.1371/journal.pone.0150780

Gardner AL. 2008. Mammals of South America 1: marsupials, xenarthrans, shrews, and bats. Chicago: University of Chicago Press.

Graham GL, Barkley LJ. 1984. Noteworthy records of bats from Peru. Journal of Mammalogy.709711. doi https://doi.org/10.2307/1380863

Gregorin R. 2009. Phylogeny of Eumops (Chiroptera: Molossidae) using morphological data. Acta Chiropterologica. 11(2):247-258. doi http://dx.doi.org/10.3161/150811009X485495

Gregorin R, Moras LM, Acosta LH, Vasconcellos KL, Poma JL, dos Santos FR, Paca RC. 2016. A new species of Eumops (Chiroptera: Molossidae) from southeastern Brazil and Bolivia. Mammalian Biology. 81(3):235-246. doi http://dx.doi.org/10.1016/j.mambio.2016.01.002

Ibáñez C, Ochoa G. 1989. New records of bats from Bolivia. Journal of Mammalogy. 70(1):216219. doi http://dx.doi.org/10.2307/1381694

Jung K, Molinari J, Kalko EKV. 2014. Driving factors for the evolution of species-specific echolocation call design in New World free-tailed bats (Molossidae). PLoS ONE. 9(1):e85279. doi http://dx.doi.org/10.1371/journal.pone.0085279

Khedkar T, Sharma R, Tiknaik A, Khedkar G, Naikwade BS, Ron TB, Haymer D. 2016. DNA barcoding using skin exuviates can improve identification and biodiversity studies of snakes. Mitochondrial DNA. 27(1):499-507. doi http://dx.doi.org/10.3109/19401736.2014.905830

Kimura M. 1980. A simple method for estimating evolutionary rates of base substitutions through comparative studies of nucleotide sequences. Journal of Molecular Evolution. 16(2):111-120. doi http://dx.doi.org/10.1007/BF01731581

Koopman KF. 1982. Biogeography of the bats of South America. Mammalian Biology. 6:273-302

Kress WJ, García-Robledo C, Uriarte M, Erickson DL. 2015. DNA barcodes for ecology, evolution, and conservation. Trends in Ecology \& Evolution. 30(1):25-35. doi http://dx.doi.org/10.1016/j.tree.2014.10.008

Lanfear R, Calcott B, Ho SY, Guindon S. 2012. PartitionFinder: combined selection of partitioning schemes and substitution models for phylogenetic analyses. Molecular Biology and Evolution. 29(6):1695-1701. doi http://dx.doi.org/10.1093/molbev/mss020

Laurance WF, Camargo JLC, Fearnside PM, Lovejoy TE, Williamson GB, Mesquita RCG, Meyer CFJ, Bobrowiec PED, Laurance SG. 2017. An Amazonian rainforest and its fragments as a laboratory of global change. Biological Reviews doi http://dx.doi.org/10.1111/brv.12343.

Lee T, Bradley RD. 1992. New distributional records of some mammals from Honduras. Texas Journal of Science. 44(1):109-111

Lim B, Arcila Hernandez LM. 2015. DNA barcoding of Jamaican bats: implications to Neotropical $\begin{array}{llll}\text { biodiversity. } & \text { Mitochondrial 27(4):3013-3019. DNA. doi }\end{array}$ http://dx.doi.org/10.3109/19401736.2015.1063047 
López-Baucells A, Rocha R, García-Mayes I, Vulinec K, Meyer CFJ. 2013. First record of Micronycteris sanborni (Chiroptera: Phyllostomidae) from Central Amazonia, Brazil: range expansion and description of its echolocation. Mammalia. 78(1):127-132. doi http://dx.doi.org/10.1515/mammalia-2013-0006

López-Baucells A, Rocha R, Fernández-Arellano G, Bobrowiec PED, Palmeirim JM, Meyer CFJ. 2014. Echolocation of the big red bat Lasiurus egregius (Chiroptera: Vespertilionidae) and first record from the Central Brazilian Amazon. Studies on Neotropical Fauna and Environment. 49(1):18-25. doi http://dx.doi.org/10.1080/01650521.2014.907600

López-Baucells A, Rocha R, Bobrowiec PED, Bernard E, Palmeirim J, Meyer CFJ. 2016a. Field guide to Amazonian bats. Manaus: INPA.

López-Baucells A, Rocha R, Webala P, Nair A, Uusitalo R, Sironen T, Forbes K. 2016b. Rapid assessment of bat diversity in the Taita Hills Afromontane cloud forests, southeastern Kenya. Barbastella, Journal of Bat Research. doi https://doi.org/10.14709/BarbJ.9.1.2016.04

López-Baucells A, Rocha R, Andriatafika T, Tojosoa T, Kemp J, Forbes K, Cabeza M. 2017a. Roost selection by synanthropic bats in rural Madagascar: what makes non-traditional structures so tempting? Hystrix. doi http://dx.doi.org/10.4404/hystrix-28.1-12046

López-Baucells A, Torrent, Rocha R, Pavan AC, Bobrowiec PED, Meyer CFJ 2017b. Does it sound familiar? Geographical variation in the high-duty cycle echolocation of the cryptic common mustached bat Pteronotus cf. rubiginosus (Mormoopidae). Bioacoustics. doi $10.1080 / 09524622.2017 .1357145$

Lovejoy TE, Bierregaard R. 1990. Central Amazonian forests and the minimum critical size of ecosystems project. In: Four neotropical rainforests. London: Yale University Press. p. 60-71.

Medina CE, Pari A, Delgado W, Zamora HT, Zeballos H, Pino K. 2012. Primer registro de Eumops patagonicus y ampliación del rango de distribución geográfica de E. hansae (Chiroptera: Molossidae) en Perú. Mastozoologia Neotropical. 19(2):163-178

Medina CE, Gregorin R, Zeballos H, Zamora HT, Moras LM. 2014. A new species of Eumops (Chiroptera: Molossidae) from southwestern Peru. Zootaxa. 3878(1):19-36. doi http://dx.doi.org/10.11646/zootaxa.3878.1.2.

Moras LM, Gomes AM, da Cunha Tavares V. 2015. Distribution and taxonomy of the common bigeared bat Micronycteris microtis (Chiroptera: Phyllostomidae) in South America. Mammalia. 79(4):439-447. doi https://doi.org/10.1515/mammalia-2014-0057

Nagy ZT, Sonet G, Glaw F, Vences M. 2012. First large-scale DNA barcoding assessment of reptiles in the biodiversity hotspot of Madagascar, based on newly designed COI primers. PLoS ONE. 7(3):e34506. doi http://dx.doi.org/10.1371/journal.pone.0034506

Ochoa G, J, Castellanos H, Ibanez C. 1988. Records of bats and rodents from Venezuela. Mammalia. 52(2):175-180. doi https://doi.org/10.1515/mamm.1988.52.2.175

Paglia A, Fonseca G, Rylands A, Herrmann G, Aguiar L, Chiarello A. 2012. Annotated Checklist of Brazilian Mammals. Occasional papers in conservation Biology. 2nd ed. Arlington, VA: Conservation International.

Pineda W, Rodríguez-Herrera B, Timm RM. 2008. Rediscovery, ecology, and identification of rare free-tailed bats (Chiroptera: Molossidae) in Costa Rica. Acta Chiropterologica. 10(1):97-102. doi http://dx.doi.org/10.3161/150811008X331135 
Ratnasingham S, Hebert PD. 2007. BOLD: The Barcode of Life Data System

Rocha R, Ovaskainen O, López-Baucells A, Farneda FZ, Ferreira DF, Bobrowiec PED, Cabeza M. Palmeirim JM, Meyer CFJ. 2017. Design matters: an evaluation of the impact of small man-made forest clearings on tropical bats using a before-after-control-impact design. Forest Ecology and Management 401(1):8:16 doi https://doi.org/10.1016/j.foreco.2017.06

Rocha R, López-Baucells A, Farneda FZ, Groenenberg M, Bobrowiec PED, Cabeza M, Palmeirim JM, Meyer CFJ. 2016. Consequences of a large-scale fragmentation experiment for Neotropical bats: disentangling the relative importance of local and landscape-scale effects. Landscape Ecology. 32(1):31-45. doi http://dx.doi.org/10.1007/s10980-016-0425-3

Ronquist F, Teslenko M, van der Mark P, Ayres DL, Darling A, Höhna S, Larget B, Liu L, Suchard MA, Huelsenbeck JP. 2012. MrBayes 3.2: Efficient bayesian phylogenetic inference and model choice across a large model space. Systematic Biology. 61(3):539-542. doi http://dx.doi.org/10.1093/sysbio/sys029

Russo D, Jones G. 2002. Identification of twenty-two bat species (Mammalia: Chiroptera) from Italy by analysis of time-expanded recordings of echolocation calls. Journal of Zoology. 258:91103. doi http://dx.doi.org/10.1017/S0952836902001231

Sambrook J, Russell DW. 2001. Molecular cloning: a laboratory manual. 3rd ed. New York: Cold Spring Harbor Laboratory Press.

Sanborn CC. 1932. The bats of the genus Eumops. Journal of Mammalogy. 13(4):347-357. doi https://doi.org/10.2307/1374140

Seyhan D, Turan C. 2016. DNA barcoding of Scombrid species in the Turkish marine waters. Journal of the Black Sea / Mediterranean environment. 22(1):35-45

Simmons NB, Voss RS. 1998. The Mammals of Paracou, French Guiana: A neotropical lowland rainforest fauna. Part 1 Bats. New York: American Museum of Natural History.

Simmons NB. 2005. Order chiroptera. In: Mammal species of the world: a taxonomic and geographic reference. Maryland: Johns Hopkins University Press Baltimore. p. 312-529.

Sodré MM, da Rosa AR, Gregorin R, Guimarães MM. 2008. Range extension for Thomas' Mastiff bat Eumops maurus (Chiroptera: Molossidae) in northern, central and southeastern Brazil. Revista Brasileira De Zoologia. 25(2):379-382. doi http://dx.doi.org/10.1590/S0101-81752008000200027

Stamatakis A. 2014. RAxML version 8: a tool for phylogenetic analysis and post-analysis of large phylogenies. Bioinformatics. 30(9):1312-1313. doi http://dx.doi.org/10.1093/bioinformatics/btu033

Tamura K, Stecher G, Peterson D, Filipski A, Kumar S. 2013. MEGA6: molecular evolutionary genetics analysis version 6.0. Molecular Biology and Evolution. 30(12):2725-2729. doi http://dx.doi.org/10.1093/molbev/mst197

Tavares VDC, Gardner AL, Ramírez-Chaves HE, Velazco PM. 2014. Systematics of Vampyressa melissa Thomas, 1926 (Chiroptera: Phyllostomidae), with descriptions of two new species of Vampyressa. American Museum Novitates. (3813):1-27. doi http://dx.doi.org/10.1206/3813.1

Thomas O. 1901. On a Collection of Mammals from the Kanuku Mountains, British Guiana. Journal of Natural History. 8(44):139-154. doi http://dx.doi.org/10.1080/03745480109442900 


\section{Tables}

Table 1. External and craniodental measurements $(\mathrm{mm})$ of Eumops hansae. Mean $\pm \mathrm{SE}$, observed range (in parentheses), and sample size are provided. See text for an explanation of variable acronyms.

\begin{tabular}{|c|c|c|c|c|}
\hline Location & Manaus (Brazil) ${ }^{1}$ & $\begin{array}{l}\text { Santa Catarina } \\
\text { (Brazil) }\end{array}$ & São Paulo (Brazil) & Several $^{2}$ \\
\hline $\mathbf{n}$ & 3 & 1 (Holotype) & 1 & 5 (skull: 4) \\
\hline Collection number & INPA 6732 & USNM 2009 & MZUSP 15442 & \\
\hline Age / Sex & Adult $ㅇ$ & Adult $\widehat{\partial}$ & Adult $\hat{\sigma}$ & Adult $q$ \\
\hline
\end{tabular}

EXTERNAL MEASUREMENTS

TL

TAIL

ThL

$\mathrm{Na}$

Cal

AntW

AntH

HF

E

FA

TiL

MET-IV

PHA1-IV
$55.5 \pm 4.3(50.5-58.1)$

$27.5 \pm 1.6(25.8-29)$

$4.7 \pm 0.5(4.1-5)$

$1.03 \pm 0.2(0.9-1.3)$

$12.9 \pm 1.6(11.3-14.4)$

$5.4 \pm 0.3(5.1-5.7)$

$4.3 \pm 0.3(3.9-4.5)$

$8.1 \pm 1.2(6.8-9.1)$

$17.7 \pm 2.5(15.1-20.1)$

$37.9 \pm 0.6(37.2-38.4) \quad 41.57$

$13 \pm 0.9(12-13.5)$
14.28

41.1 $37.8 \pm 0.34$

41.01

41.44

14.7

\section{CRANIODENTAL MEASUREMENTS}

$\begin{array}{llll}\text { GLS } & 20.16 & 21.5 & 18.86 \pm 0.20 \\ \text { CIL } & 18.73 & 20.56 & 17.90 \pm 0.12 \\ \text { ZB } & 11.95 & 12.75 & 10.83 \\ \text { PB } & 4.26 & 4.19 & 4.0 \pm 0.04 \\ \text { BB } & 9.09 & 9.13 & 6.89 \pm 0.08 \\ \text { MTRL } & 7.32 & 7.87 & \\ \text { BAM } & 8.34 & 8.8 & \\ \text { BAC } & 4.94 & 5.17 & \\ \text { MANDL } & 14.44 & 15.85 & \\ \text { MANDTL } & 7.62 & 7.88 & \end{array}$

${ }^{1}$ Only 1 specimen collected. ${ }^{2}$ Five females reported in Eger (1977) collected from localities in Costa Rica $(n=1)$, Guiana $(\mathrm{n}=2)$, Panama $(\mathrm{n}=1)$, Venezuela $(\mathrm{n}=1)$. Abbreviations are as follows: INPA (National Institute of Amazonian Research, Manaus, Brazil); USNM (National Museum of Natural History, Washington, USA); MZUSP (Museum of Zoology of the University of São Paulo, São Paulo, Brazil). 
Table 2: External and craniodental measurements (mm) of Eumops maurus. Mean \pm SE, observed range (in parentheses), and sample size are provided. See text for an explanation of variable acronyms. All measurements except for our specimens were taken from literature.

\begin{tabular}{|c|c|c|c|c|c|c|c|c|}
\hline Location & Manaus (Brazil) $^{1}$ & Tocantins and Goiás (Brazil) $^{2}$ & Guiana & Venezuela & Ecuador & Suriname & Peru & São Paulo (Brazil) \\
\hline $\mathbf{n}$ & 3 & 5 & 1 & 1 & 1 & 1 & 1 & 1 \\
\hline $\begin{array}{l}\text { Collection } \\
\text { number }\end{array}$ & INPA 6731 & & $\begin{array}{l}\text { BMNH } \\
1.6 .434\end{array}$ & $\begin{array}{l}\text { EBRG } \\
16124\end{array}$ & $\begin{array}{l}\text { ROM } \\
106326\end{array}$ & $\begin{array}{l}\text { RNH } \\
12943 * *\end{array}$ & CML 7559 & CCZ 761 \\
\hline Age & Adult $\widehat{\partial}$ & Adult $\partial^{\lambda}$ & Adult $\widehat{\partial}$ & Adult ㅇ & Adult ㅇ & Adult ㅇ & Adult? & Adult $q$ \\
\hline
\end{tabular}

$\begin{array}{lllll}\text { TL } & 65.4 \pm 3.4(62.5- & 73 \pm 7.2(62.8-81) 5 & 69.6 \pm 2.6(67.7-76.4) & 63 \\ & 69.2) & & & \\ \text { TAIL } & 42.6 \pm 3.6(39.7- & 47 \pm 3.5(43.3-52.1) 5 & 47.4 \pm 2.3(44-51.4) & 50.5\end{array}$

ThL $\quad 46.6)$

$\mathrm{Na} \quad 1.1 \pm 0.3(0.8-1.3)$

Cal $22.5 \pm 0.9(21.5$

23.2)

AntW $\quad 5.4 \pm 0.4(5-5.7)$

AntH $\quad 4.6 \pm 0.3(4.4-5)$

$\begin{array}{ll}\text { AntH } & 4.6 \pm 0.3(4.4-5) \\ \text { HF } & 10.8 \pm 1.2(9.7-12.1)\end{array}$

E

$21.1 \pm 0.8(20.2$

21.7)

$21.4 \pm 3.1(17.8-25.1) \quad 9.5$

50.5

FA $53.2 \pm 1.1(52.5-$

$54.5)$

$5 \quad 22.4 \pm 1.2(20.1-24.3) \quad 19$

9.5
19

$57.6 \pm 2.1(54.9-60.8) \quad 55.3 \pm 2.2(52.7-59.1) \quad 53.1$

53.1

$18.1 \pm 0.5(17.7$

TiL

18.6)

16.7
51.9
20.3

MET-IV

51.7
19.4

51.9
20.3

CRANIODENTAL CHARACTERS

\begin{tabular}{|c|c|c|c|c|c|c|c|c|}
\hline GLS & 21.5 & $22.6,22.7$ & 20.6 & 21.3 & 20.8 & 21.4 & 20 & 22.8 \\
\hline CIL & 20.3 & $21.6,21.7$ & 20.1 & 19.9 & 19.2 & 19.4 & 18.9 & 21.8 \\
\hline ZB & - & 13.2 & 12.3 & 12.1 & 12 & 12.5 & 12.4 & 13.1 \\
\hline PB & 4.2 & $4,4.1$ & 4.9 & 4 & 4 & 4.1 & 4.3 & 3.9 \\
\hline BB & 9.9 & & 9.7 & & 9.9 & 10.2 & 10.5 & \\
\hline MTRL & 8.4 & 9 & 8.2 & 8.2 & 8.1 & 8.4 & 7.6 & 9 \\
\hline BAM & 9.3 & 9.2 & 8.9 & 8.7 & 8.3 & 8.9 & 8.3 & 9.1 \\
\hline BAC & 5.4 & & 5.2 & & 4.9 & 5.1 & 5 & \\
\hline MANDL & 15.9 & $17.1,17.2$ & 15 & & 14.9 & & 15.2 & 16.9 \\
\hline MANDTL & 9.05 & & 8.6 & & 8.4 & 9 & 8.3 & \\
\hline
\end{tabular}




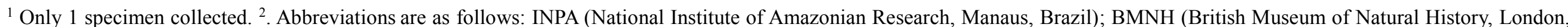

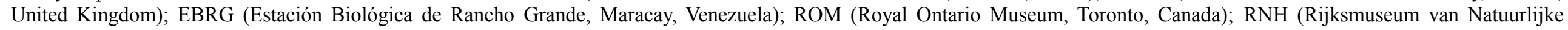
Historie, Leiden, Netherlands); CML (Colección Mamíferos Lillo, Tucumán, Argentina); CCZ (Centro de Controle de Zoonoses). 
Table 3: Search flight call parameters for Eumops maurus, E. hansae and other Eumops species. Mean \pm SE, observed range (in parentheses).

\begin{tabular}{|c|c|c|c|c|c|c|c|}
\hline Species & Source & $\mathbf{N}(\mathbf{n}) *$ & Call type & Call shape & FME & Start frequency & End frequency \\
\hline E. maurus & Current study & $49(2)$ & mono & QCFd & $25.29 \pm 2.613(19.2-30.8)$ & $33.45 \pm 2.86(25.6-39.1)$ & $19.80 \pm 2.72(14.3-24.3)$ \\
\hline E. hansae & Current study & $24(2)$ & mono & QCFd & $21.86 \pm 1.79(17.9-23.9)$ & $34.77 \pm 3.83(25.6-40.1)$ & $13.78 \pm 1.96(11-16.8)$ \\
\hline \multirow[t]{7}{*}{ E. auripendulus } & Personal recordings & 6 & low & QCFd & $23.13 \pm 1.76(16.4-27.5)$ & $34.35 \pm 3.13(23.8-42.2)$ & $19.97 \pm 2.63(12-26.7)$ \\
\hline & Barataud (2013) & 2 & low & QCFd & $26.70(26.3-27)$ & & \\
\hline & Jung et al. (2014) & $41(9)$ & low & $\mathrm{FMu} / \mathrm{QCFd}$ & & $32.4 \pm 4.3$ & $18.2 \pm 1.6$ \\
\hline & Barataud (2013) & 16 & middle & $\mathrm{FMd} / \mathrm{QCF}$ & $23.30(20.1-25.7)$ & & \\
\hline & Current study & 6 & high & QCFd & $25.77 \pm 2.01(23.1-28.7)$ & $28.59 \pm 2.32(25.9-33.7)$ & $24.73 \pm 2.20(21.2-27.7)$ \\
\hline & Barataud (2013) & 22 & high & QCF & $18.70(17.3-21.8)$ & & \\
\hline & Jung (2014) & $27(9)$ & high & FMu/QCFd & & $35.8 \pm 4.1$ & $21.9 \pm 1.6$ \\
\hline \multirow[t]{2}{*}{ E. dabbenei } & Jung et al. (2014) & $22(6)$ & low & $\mathrm{FMu} / \mathrm{QCFd}$ & & $21.3 \pm 1.2$ & $13.7 \pm 0.5$ \\
\hline & Jung et al. (2014) & $23(6)$ & high & $\mathrm{FMu} / \mathrm{QCFd}$ & & $24.6 \pm 2.3$ & $15.8 \pm 0.8$ \\
\hline \multirow[t]{2}{*}{ E. glaucinus } & Jung et al. (2014) & $37(10)$ & low & $\mathrm{FMu} / \mathrm{QCFd}$ & & $27.4 \pm 3.4$ & $19 \pm 0.4$ \\
\hline & Jung et al. (2014) & $16(10)$ & high & $\mathrm{FMu} / \mathrm{QCFd}$ & & $29.3 \pm 4.2$ & $20.3 \pm 0.3$ \\
\hline \multirow[t]{2}{*}{ E. nanus } & Jung et al. (2014) & $8(4)$ & low & $\mathrm{FM} / \mathrm{QCFd}$ & & $27.9 \pm 0.1$ & $25.2 \pm 0.2$ \\
\hline & Jung et al. (2014) & $9(4)$ & high & FM/QCFd & & $30.5 \pm 2.5$ & $26.8 \pm 0.8$ \\
\hline E. underwoodi & Miller (2003) & $1046(150)$ & mono & QCFd & $16.25 \pm 4.2(12.43-20.75)$ & $15.4 \pm 2.88(12.43-18.18)$ & $18.09 \pm 2.7(15.76-21.05)$ \\
\hline
\end{tabular}

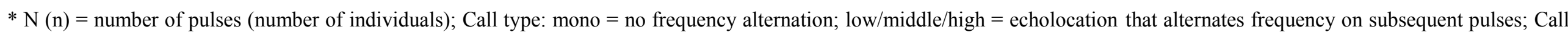
shape: $\mathrm{QCF}=$ Quasi Constant Frequency; FM = Frequency Modulated; $\mathrm{u}=$ upward-modulated; $\mathrm{d}=$ downward-modulated; FME: Frequency of maximum energy 
Table 4: Average pairwise Kimura 2-parameter percentage sequence divergence among Eumops species based on 657 base pairs of the COI gene for 26 individuals. Intraspecific divergence is on the diagonal.

\begin{tabular}{llcccccc}
\hline & $\mathrm{n}$ & E. auripendulus & E. floridanus & E. hansae & E. maurus & E. perotis & E. underwoodi \\
\hline E. auripendulus & 8 & 0.3 & & & & & \\
E. floridanus & 2 & 12.4 & 0.0 & & & & \\
E. hansae & 12 & 16.3 & 13.4 & 0.9 & & & \\
E. maurus & 2 & 3.2 & 12.9 & 16.5 & 0.0 & & \\
E. perotis & 1 & 12.1 & 10.0 & 17.4 & 11.8 & - & \\
E. underwoodi & 1 & 14.0 & 10.4 & 17.1 & 13.2 & 10.3 & - \\
\hline
\end{tabular}

Table 5. List of taxa used in the present study and BOLD and GenBank accession numbers.

\begin{tabular}{ll}
\hline Species & Accession numbers (GenBank) \\
\hline Eumops auripendulus & EF080345 - EF080349; JF448843; JF454657; KR608253 \\
Eumops hansae & EF080350 - EF080357; JF435947; JF44884, BOLDAAC7539 \\
Eumops maurus & JF448845; BOLDAAY3575 \\
Eumops perotis & KP4219 \\
Eumops underwoodi & KP734223 \\
Eumops floridanus & KR337728, KR337729 \\
Tadarida brasiliensis & JF446884 \\
\hline
\end{tabular}




\section{Figures}

Fig. 1 Distribution of Eumops maurus and E. hansae in South America. [1] Pompeya Sur, Napo Province, Ecuador (Reid et al., 2000); [2] Uverito, State of Monagas, Venezuela (Sánchez et al., 1992); [3] Kanaku mountains, Guiana (holotype) (Thomas, 1901); [4] Peixe/Angical Hydroelectric Plant, State of Tocantins (Sodré et al., 2008); [5] Corumbá Hydroelectric Plant IV, State of Goiás (Sodré et al., 2008); [6] São Paulo, State of São Paulo (Sodré et al., 2008); [7] Santuario Nacional Pampas, Peru (Luna et al., 2002); [8] San Juan: Asociación de Viviendas 15 de Mayo, Peru (Diaz et al., 2011); [9] Chiapas, Mexico (Álvarez and Álvarez-Castañeda, 1990); [10] Lancetilla Atlantida, Honduras (Lee and Bradley, 1992) [11] Several locations, Costa Rica (Eger, 1977; Gardner, 2008; Hall, 1981); [12] Peru (Graham and Barkley, 1984); [13] Venezuela (Eisenberg, 1989); [14] Venezuela (Handley, 1976); [15] French Guiana (Simmons and Voss, 1998); [16] Manaus, State of Amazonas (Handley, 1955); [17] Bolivia (Ibáñez and Ochoa, 1989); [18] Uberlândia, Minas Gerais (Stutz et al., 2004); [19] São Paulo (Novais unpublished); [20] Colônia Hansa, Joinville, Santa Catarina (holotype) (Sanborn 1932). According to Eger (1977), in Suriname and Brazil there are two E. hansae with imprecise location. Map downloaded and adapted from the map of National Aggregates of Geospatial Data Collection (NAGDC): Population, Landscape and Climate Estimates, v3: Biomes South America; from the NASA Socioeconomic Data and Applications Center (SEDAC) at http://sedac.ciesin.columbia.edu/data/collection/groads/maps/gallery/search. Accessed on 20/08/2015.

Fig 2. Eumops maurus (INPA 6731; male). - A. Dorsal view. - B. Ventral view. - C. Lateral view. E. hansae (INPA 6732; female). - D. Dorsal view. - E. Ventral view. - F. Lateral view. Note the large and well-defined basisphenoid pits and the third commissure of M3 developed in E. hansae (E). Scale bar: $5 \mathrm{~mm}$.

Fig. 3 Echolocation calls of Eumops maurus (A: spectrogram of single pulse; B power spectrum; C commuting flight sequence) and E. hansae (D: spectrogram of single pulse; E power spectrum; F commuting flight sequence).

Fig. 4 Tree resulting from the Bayesian analysis of COI showing the evolutionary relationships among Eumops species. Values above branches represent Bayesian posterior probabilities (BPP) and below branches, the maximum likelihood (ML) bootstrap. Our specimens are represented by asterisks. Abbreviations are as follows: BEL: Belize; BRA: Brazil; ECU: Ecuador; GUA: Guatemala; GUY: Guyana; PER: Peru; USA: United States of America. 


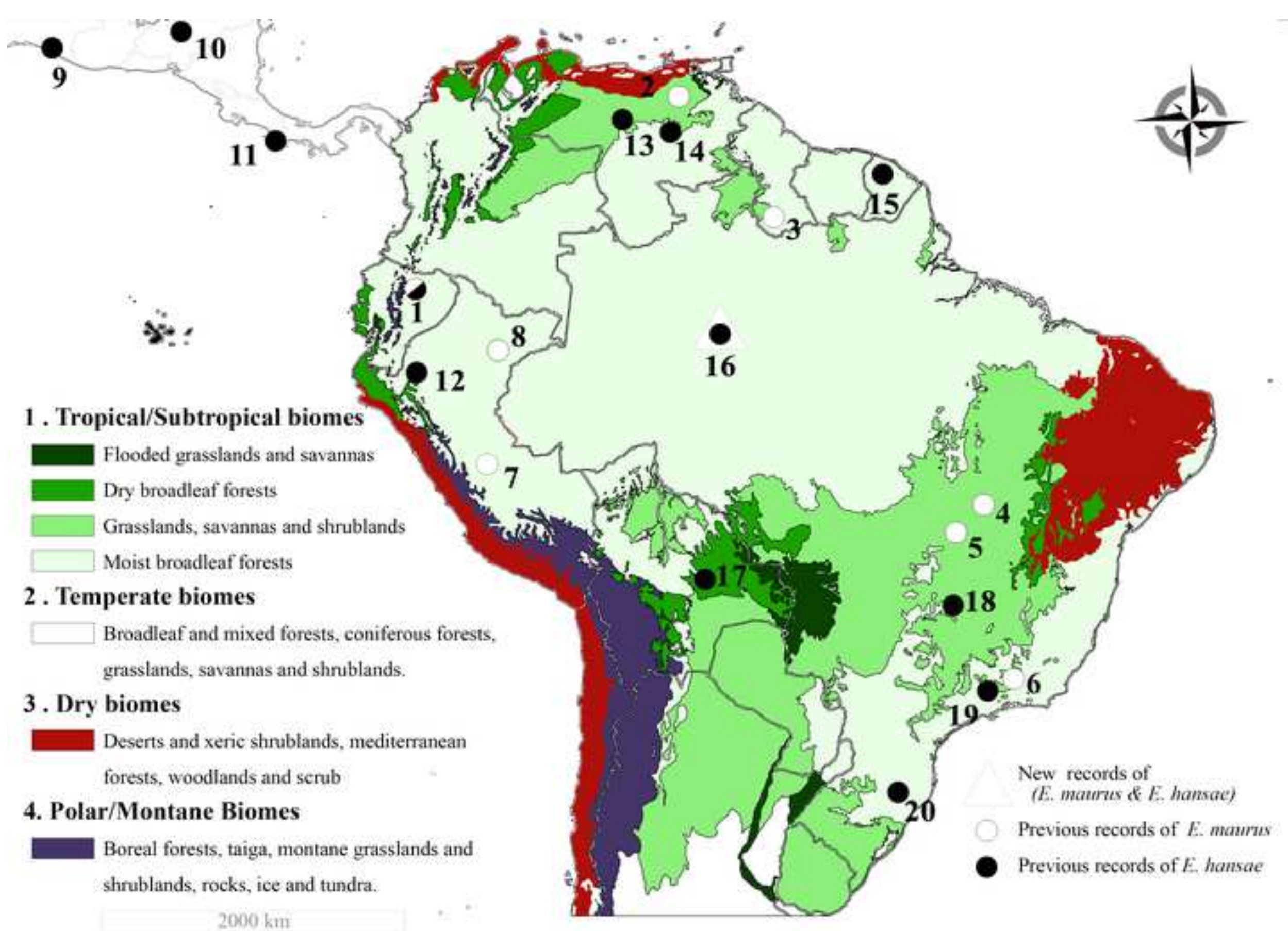


A

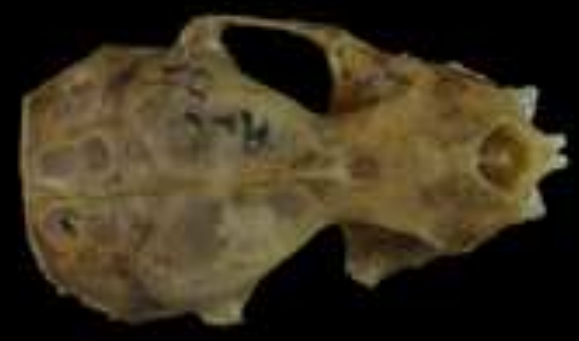

B

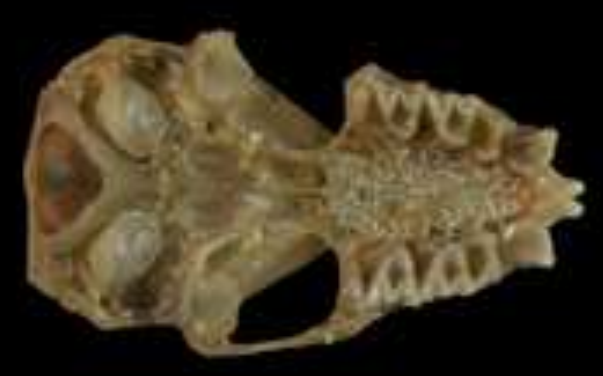

C

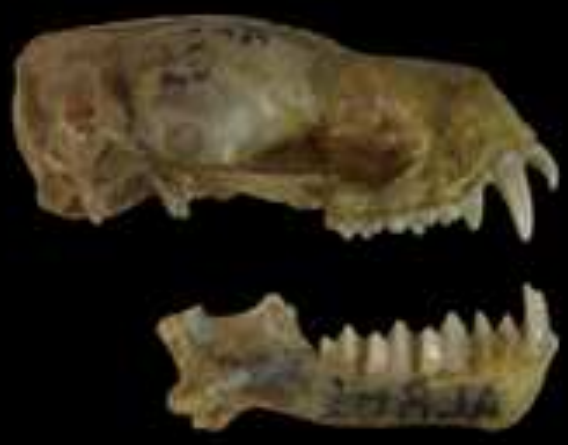

D

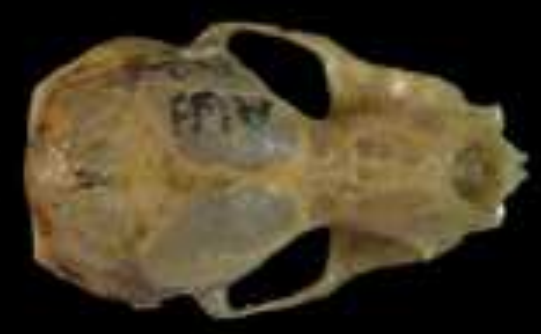

E

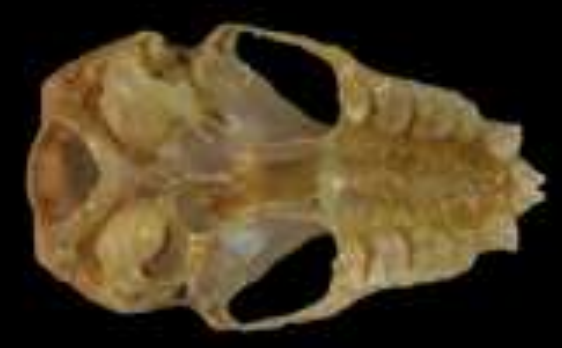

F

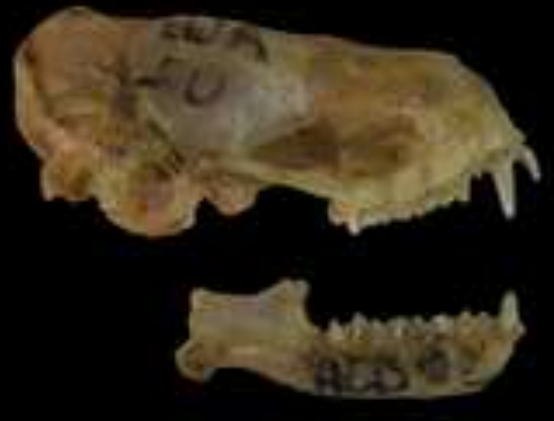




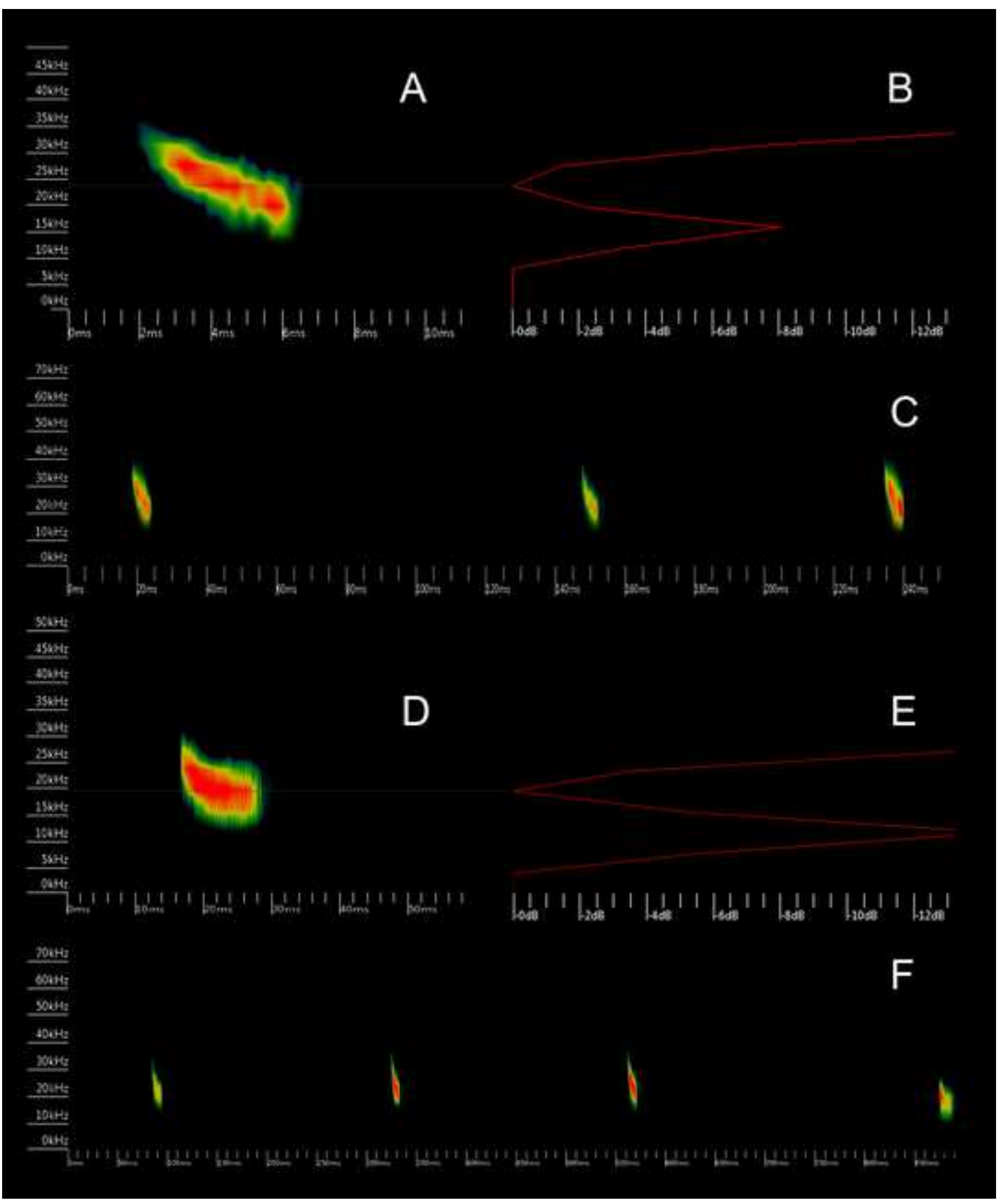




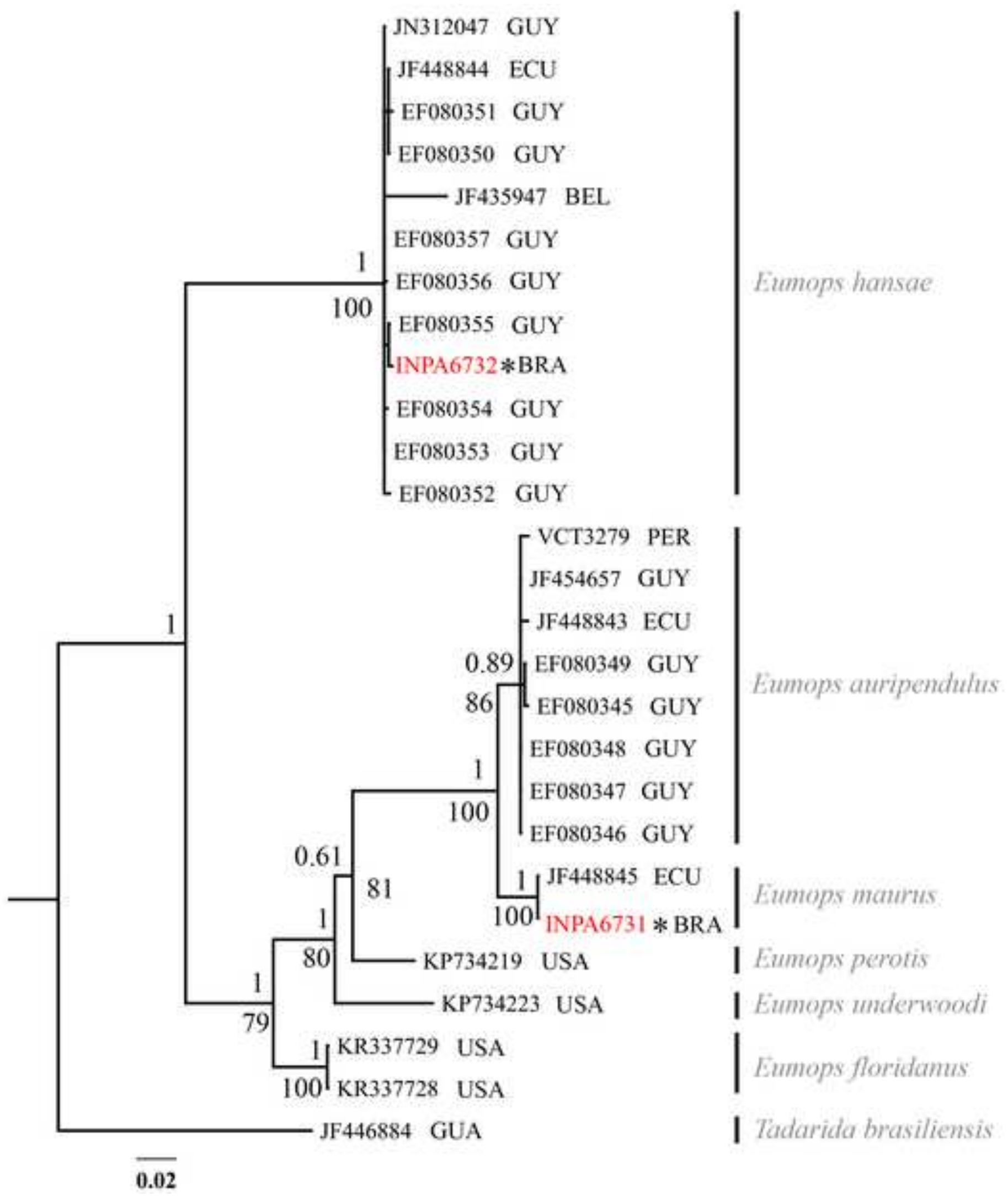

